\title{
OS MITOS SOBRE O OZÔNIO: UM RESGATE DAS ORIGENS DA DISCUSSÃO - I
}

\section{Ricardo Augusto Felicio ${ }^{1}$}

\section{Daniela de Souza Onça ${ }^{2}$}

RESUMO: Entre os anos de 1980 a 1990 o mundo observou a maior ação de retaliação a uma substância de amplo emprego mundial, baseando-se em uma hipótese científica que nunca foi comprovada: a chamada destruição da "camada de ozônio" realizada por cloro originado de uma família de gases refrigerantes, os CFCs. Muito se falou sobre a influência humana, mas pouco se levantou sobre os fatores naturais, as escalas e a imensa discussão que ocorreu no mundo desenvolvido. Em países como o Brasil, as vozes discordantes, além de serem exíguas, foram ainda silenciadas ao máximo para que não divulgassem as discussões postas. O presente trabalho foi dividido em duas partes, sendo que esta primeira visou realizar um resgate destas discussões. Foram levantadas as bibliografias da época e os recentes trabalhos divulgados, sintetizando a informação desde o cunho da química atmosférica elencada, até os desdobramentos desta ação draconiana de impedimento do uso industrial destas substâncias. Pretende-se tornar mais claro para as pessoas que, com a hipótese do "aquecimento global", mais uma vez seu cotidiano está prestes a ser mudado, baseado em uma falácia que não tem fundamentação científica que a sustente. Ao mesmo tempo, sinaliza-se que estas burocracias acordadas em protocolos políticos tornam-se eternizadas, gerando uma máquina sem fim de consumo de recursos e criação de procedimentos impeditivos para o crescimento das sociedades emergentes.

Palavras-chave: Mudanças Climáticas. Ozônio. Mitos.

\footnotetext{
1 Prof. Dr. Climatologista, Departamento de Geografia - USP. ricaftnt@yahoo.com.

${ }^{2}$ Prof $^{\mathrm{a}}$. Dr ${ }^{\mathrm{a}}$. Climatologista, Departamento de Geografia - UDESC. danielaonca@yahoo.com.br.
} 


\section{INTRODUÇÃO}

Nos anos de 1970 foi amplamente divulgada, como pregação quase que religiosa, o medo da desertificação. A seguir a este pré-teste, o ozônio e sua variabilidade apareceram como um primeiro problema a atingir a escala mundial, como se causado diretamente pelo Homem. Seguia-se, desta forma, uma agenda criada no Clube de Roma, em 1962, onde se traçava o futuro da humanidade.

Assim como não existe vida como a conhecemos sem dióxido de carbono $\left(\mathrm{CO}_{2}\right)$, não existe ozônio natural $\left(\mathrm{O}_{3}\right)$ sem luz solar. Estas são afirmações que não podem ser refutadas. Desta forma, faz-se necessário entender o processo de formação do ozônio, sua variação e o histórico que registrou a considerada "falácia científica do século XX", onde um fenômeno natural foi transformado em uma emergência global.

O ozônio é conhecido desde a Antiga Grécia, que não era compreendido como um gás, mas já associavam a sua presença ao mau tempo. O prefixo "ozo" vem deste mesmo povo que the atribuiu o significado de "com aroma ou cheiro forte e característico"; algumas definições o descrevem como penetrante e desagradável. A literatura registrou ao químico alemão Christian Friedrich Schönbein a descoberta desta molécula, exatamente como os gregos a pressentiam: pelo cheiro acre, oxidante e forte que aparecia durante as trovoadas, as quais, através de seus relâmpagos, fazem a eletrossíntese das moléculas, utilizando o próprio oxigênio molecular $\left(\mathrm{O}_{2}\right)$ presente no ar (TOMASONI, 2011). Desta forma, ela necessita de energia para a sua formação, e por ser uma substância altamente reativa, constitui-se de uma das componentes variáveis da atmosfera da Terra, que se recicla o tempo todo em processos naturais, dos quais o principal, a radiação solar, será abordada neste artigo.

\section{OBJETIVOS}

Apresentar, neste primeiro volume, uma discussão sobre a fragilidade da hipótese antrópica da depleção do ozônio. Desta forma, elencaram-se as informações de como 
esta serviu de legitimação para as ações deletérias de desenvolvimento nos países subdesenvolvidos, refletindo também nas pequenas empresas dos países desenvolvidos.

\section{MATERIAL E MÉTODOS}

A pesquisa foi realizada sobre a bibliografia desde os anos de 1990 até as atuais, levantadas de autores nacionais e internacionais, dando ênfase a estes últimos, pois tiveram mais exposição às informações sobre as discussões científicas, tecnológicas e políticas, as quais foram categoricamente cerceadas de divulgação aqui no Brasil, quando este passava por um período de grande instabilidade econômica-financeira, o que refletiu diretamente nas análises e tomadas de decisões.

As conclusões deste primeiro volume são parciais, deixando aberta a discussão sobre o assunto, mas mostrando definitivamente que a hipótese antrópica é altamente questionável.

\section{DISCUSSÃO DOS ELEMENTOS}

\subsection{As Primeiras Camadas da Atmosfera e a Formação do Ozônio}

O entendimento da formação do ozônio necessita da interpretação de alguns pontos básicos e importantes da física e química da atmosfera. A constituição dos gases atmosféricos apresenta-se praticamente estável até a altitude de $80 \mathrm{~km}$. Os gases majoritários são nitrogênio, com 78,0\% e oxigênio, com 21,0\%. O argônio elenca a terceira e baixa posição, com apenas $0,93 \%$. Todos os outros são chamados de traços, contidos em 0,07\%. O gás oxigênio, com dois átomos em sua formação, é chamado de oxigênio molecular. Atua como a matéria prima para a formação do gás ozônio, que se tornará um estado transitório do oxigênio, quando passar a possuir três átomos em sua formação. O tempo de vida do ozônio na atmosfera é muito curto, devido a sua molécula ser altamente reativa. O ozônio necessita de energia que consiga provocar uma instabilidade no estável oxigênio molecular. A única fonte de energia é a proveniente do 
Sol, na freqüência das ondas curtas, especialmente a radiação ultravioleta. Como a atmosfera da Terra age de forma seletiva às energias externas ao sistema, as freqüências do ultravioleta são as primeiras a serem barradas, começando a ocorrer em alta altitude. Esta interação necessita de massa, ou seja, de moléculas.

A troposfera, a primeira camada da atmosfera, próxima da superfície da Terra, comporta cerca de $90 \%$ de toda a massa. Além dela existe uma camada intermediária chamada tropopausa e acima desta, a estratosfera, onde a pressão atmosférica pode variar de $50 \mathrm{mb}$, na parte mais baixa, a $10 \mathrm{mb}$, na parte mais alta, sendo extremamente tênue, pois a Pressão ao Nível Médio do Mar - PNMM é de 1013,25mb. Porém, mesmo com uma densidade tênue, a massa atmosférica é suficiente para que as interações com os comprimentos de onda curta eletromagnéticos da radiação ultravioleta provenientes do Sol possam ocorrer em toda a extensão da estratosfera. Como a densidade é maior na camada mais baixa da estratosfera, teremos como resultante a maior concentração do gás ozônio. Quanto às temperaturas, os maiores valores, entendidos como energia cinética, são registrados na parte mais alta, pois estas moléculas interceptam os raios eletromagnéticos de maior energia. Desta forma, a estratosfera apresenta um perfil altamente estável, pois é quente na parte de cima, geralmente apresentando zero grau Celsius e fria na parte de baixo, com cerca de $-56,0^{\circ} \mathrm{C}$, valores médios verificados em uma atmosfera considerada padrão pela Organização Meteorológica Mundial.

Durante o processo de interceptação da radiação, ocorre a fotólise ou fotodissociação, onde as moléculas são rompidas, formando alguns radicais ou átomos livres. No processo, a energia ultravioleta é absorvida para romper a estabilidade molecular, resultando em uma emissão de radiação de ondas longas, na banda do infravermelho, que por sua vez aquece consideravelmente a camada. Desta forma, deve-se entender que todas as moléculas que atingirem a estratosfera ou qualquer camada superior serão fotodissociadas pela radiação incidente de alta energia. Assim, os dois gases majoritários, nitrogênio e depois o oxigênio, estão muito mais sujeitos a estes processos. Como a quantidade de oxigênio e a radiação UV C são muito grandes, a formação do ozônio é estimada em cerca de vários milhões de toneladas por segundo, pois só assim conseguiria contribuir significativamente para aquecer e estabilizar a estratosfera. 
Assim, o ozônio é um gás que se forma quando o segundo gás majoritário da atmosfera, o gás oxigênio interage com a radiação ultravioleta da banda C - UV C, altamente nociva aos seres vivos. Nestes termos, esta radiação fatal não chega à superfície por causa do oxigênio molecular. Desta interação surge o oxigênio atômico (O'), altamente instável, mas necessário para ser o precursor da formação do ozônio. A seguir, em sua curta existência, o ozônio interage também com a radiação ultravioleta, mas por sua propriedade química, a freqüência da interação ocorre na banda B - UV B, em uma altitude pelo menos $10 \mathrm{~km}$ mais alta que a altitude de sua formação. Desta forma, o controle da incidência de radiação ultravioleta B sobre a superfície terrestre é dosada pela concentração de ozônio na estratosfera, que se apresenta altamente volátil, pois as chances de uma molécula de ozônio encontrar outra são muito altas e quando isto ocorre, surgem três moléculas de gás oxigênio novamente, retornando à estabilidade e liberando mais calor na estratosfera. $O$ processo de câmbio entre estes gases é expressivamente rápido. Como a concentração de gases é maior na base da estratosfera, a concentração de ozônio $\left(\mathrm{O}_{3}\right)$ também o será e assim, toda esta parte da base da estratosfera é conhecida como ozonosfera, por conter a maior parte da concentração de nuvens ozônicas que se formam e desaparecem com incrível rapidez. Assim, não existe a tal "camada de ozônio", mas sim este setor de maior probabilidade de se observar a sua formação. Notemos que a radiação ultravioleta A - UV A, não possui a mesma interação com as moléculas de $\mathrm{O}_{2}$ que as radiações UV C ou UV B apresentam, participando então mais do processo de espalhamento, o que não é suficiente para bloquear boa parte do seu fluxo, que acaba incidindo na superfície da Terra (Fig.4.1.1). 


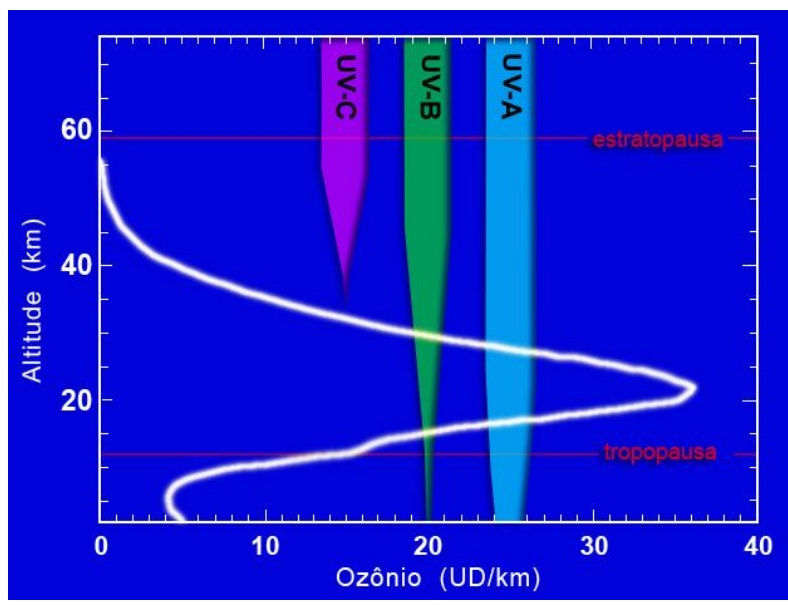

Fig.4.1.1: Bandas espectrais de radiação ultravioleta e sua extinção conforme atravessam as camadas baixas da atmosfera. A maior produção de ozônio ocorre na base da estratosfera (Fonte: adaptado por Felicio, 2009).

A produção realizada por processos fotoquímicos normalmente é insignificante abaixo de $20 \mathrm{~km}$ de altitude:

$$
\begin{aligned}
& \mathrm{O}_{2}+\mathrm{hv}(\lambda \square<242 \mathrm{~nm}) \rightarrow \mathrm{O}^{\prime}+\mathrm{O}^{\prime}-118,111 \mathrm{Kcal} . \mathrm{mol}^{-1} \\
& \mathrm{O}_{2}+\mathrm{O}^{\prime} \rightarrow \mathrm{O}_{3} \\
& \mathrm{O}_{3}+\mathrm{O}_{3} \rightarrow 3 \mathrm{O}_{2}+64 \mathrm{Kcal} . \mathrm{mol}^{-1}
\end{aligned}
$$

De fato, a quantidade de ozônio existente é tão insignificante que Gordon Miller Bourne Dobson (1889-1976), físico e meteorologista britânico, um dos principais pesquisadores sobre o assunto, criou um procedimento para a sua avaliação. Se toda a coluna de ar atmosférico fosse concentrada e reduzida a uma pressão atmosférica conhecida, ao NMM, portanto $1 \mathrm{~atm}$ ou $1013,25 \mathrm{mb}$, e em uma temperatura fixa conhecida, no caso zero grau Celsius, a espessura da quantidade total de ozônio seria de apenas $3 \mathrm{~mm}$. Dobson atribuiu cada milímetro a 100 Unidades Dobson e verificou que a média desta concentração seria de 300UD. Aqui é importante ressaltar que, exatamente como a ciência cria médias para poder se referenciar, tal como o próprio exemplo da PNMM, onde valores acima de $1013,25 \mathrm{mb}$ são considerados de alta pressão em superfície, ou anticiclones, e abaixo deste, baixa pressão atmosférica em superfície, ou ciclones, quaisquer valores acima de 300UD são apenas "anomalias" positivas e valores abaixo, "anomalias" negativas. Tais anomalias nunca deveriam ser entendidas como um problema, mas sim como parte variante de um sistema ou um processo que não é fixo e 
que ocorre há milhares de anos, se não mais. Isto é tão óbvio para a Ciência que surpreende não termos até hoje um comentário qualquer sobre o fato em si da variabilidade do parâmetro, embora existam vários artigos que relatem que tal variabilidade é natural, como o próprio Dobson demonstraria.

\subsection{A Variabilidade do Ozônio Sempre Foi Natural}

As variações da concentração de ozônio sempre existiram e foram divulgadas desde 1930. Em 1950, R. Penndorf, do laboratório da United States Air Force - USAF, ou Força Aérea dos Estados Unidos, em Cambridge, EUA, analisou dados da estação de medição de Tronsø, Norte da Noruega, de uma série de 1926 a 1942. Durante esta avaliação, verificou valores abaixo de 50UD, seguidos, na hora posterior, por valores acima de 500UD. Concluiu que a variação chegava a 1000\% de uma hora para outra, tamanho era o efeito reativo desta molécula como estado transitório do oxigênio. Foram estas anomalias que ele chamou de "buracos na camada de ozônio", como uma expressão figurativa que nunca foi levada em conta até a chegada dos anos de 1980.

Com o planejamento do Ano Geofísico Internacional - AGl marcado para acontecer em 1957 a 1958, estendido até 1959, Dobson resolveu partir para os trabalhos no continente antártico. Entre as medições diárias, concordou com o verificado anteriormente no hemisfério Norte: a variação horária é espantosa, não podendo ser utilizada sem a realização de somatórios horários e médias. Chegou a registrar valores de 125UD no pólo Sul, na estação estadunidense de Amundsen-Scott, enquanto que os franceses, em Dumont d'Urville, na costa antártica, registravam valores semelhantes, como outros na baía Halley. Desta forma, com os bancos de dados formados, inclusive com medições utilizando a fase da Lua Cheia, verificou que o cômputo do ozônio dos períodos sazonais apresentava significativa variação, com grande perda durante o inverno e recuperação somente no final da primavera. Em seu livro e artigo, Dobson publicou que as anomalias na camada de ozônio sobre a Antártida eram naturais. Dobson nunca utilizou a expressão "buraco", mesmo sendo estas anomalias sobre a Antártida mais expressivas que as verificadas no hemisfério Norte (DOBSON, 1968a; 1968b). Verificou-se que a variação do ozônio sazonal sobre a Antártida é muito mais elevada na saída dos períodos de inverno, 


\section{Mudanças Climáticas}

dada a ausência de luz solar (Fig.4.2.1). Contudo, enquanto a noite polar marca significativamente os meses centrais do ano, com a presença do Sol, a incidência de energia é vigorosa, apresentando saldo maior que a parte equatorial em energia recebida em 24 horas (Fig.4.2.2) chegando a marca de 1.400MJ.m ${ }^{-2}$ (KING e TURNER, 1997).

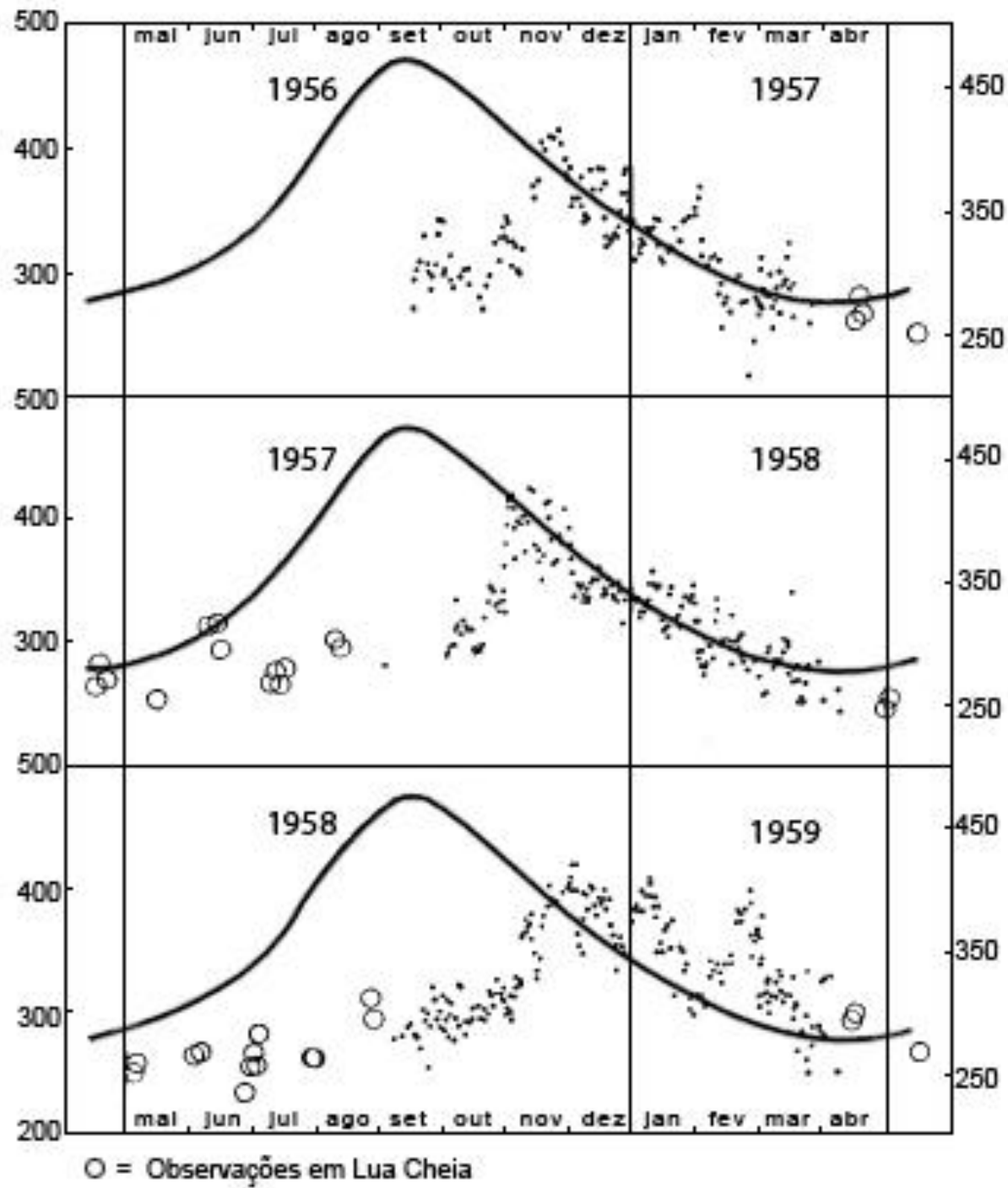

Fig.4.2.1: Os três anos de medição do Ano Geofísico Internacional. As linhas cheias são as medições do ozônio no hemisfério Norte, em Spitzbergen, Noruega (78²5'N 01600'E). Notar os baixos valores durante os meses de inverno. Os pontos e bolinhas vazadas são as medições do ozônio na baía Halley, Antártida, durante o mesmo período. Notar os baixos valores de ozônio na primavera austral e como rapidamente crescem em novembro, no tempo em que a estratosfera se aquece. Notar também o padrão invertido entre os hemisférios, demonstrando a necessidade da presença da radiação solar para a formação do ozônio. As bolinhas vazadas são medições realizadas nas fases de Lua Cheia, na Antártida (Fonte: DOBSON, 1968a, p. 401). 


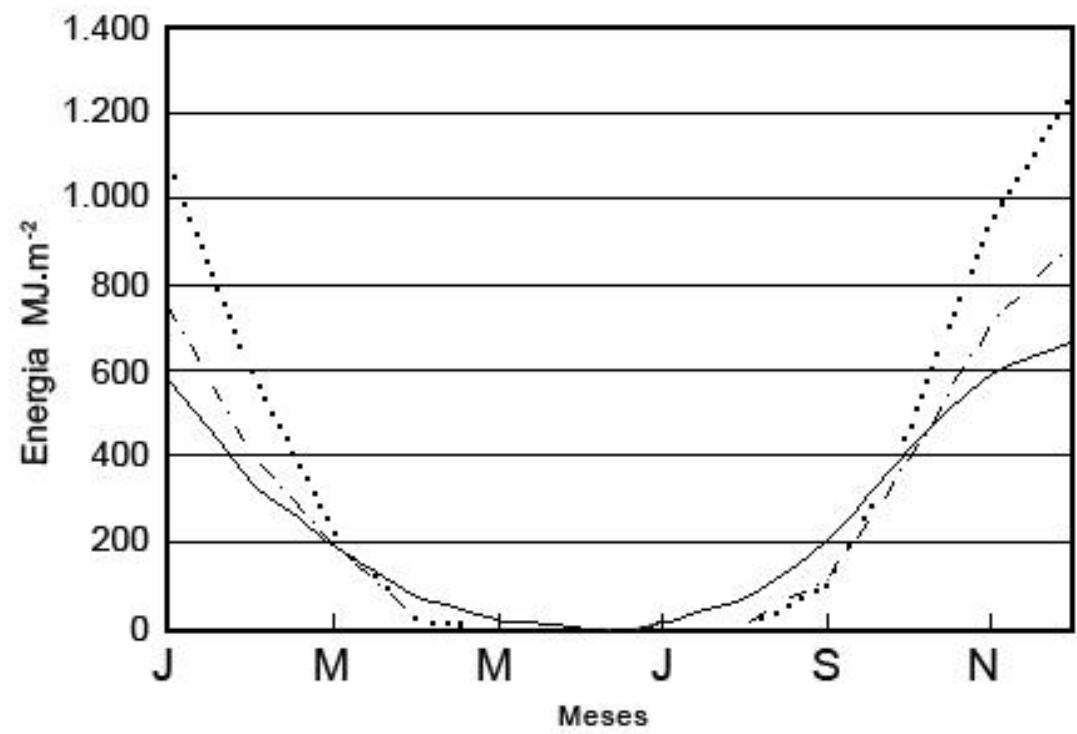

Fig.4.2.2: Somatório da radiação solar global mensal média nas estações na Antártida. Linha contínua, dados da estação britânica Faraday (Base "F" 6515'S 064¹6'W) de 1963 a 1982; linha tracejada, dados da estação britânica Halley $\left(75^{\circ} 35^{\prime} \mathrm{S} 026^{\circ} 34^{\prime} \mathrm{W}\right.$, em 2001 , pois Halley "Z" V move-se conforme se desloca a plataforma de gelo Brunt) de 1963 a 1982; e linha pontilhada, dados na estação russa Vostok (78²7'S 10650’E) de 1963 a 1973 (Fonte: KING e TURNER, 1997, p. 72).

Também é importante ressaltar que durante o período de inverno, por um problema geométrico, a radiação solar, mesmo incidindo de forma oblíqua na estratosfera, não é suficiente para prover radiação UV C para a formação de ozônio, justamente porque a atmosfera intercepta esta radiação em latitudes mais baixas, só permitindo a passagem de radiação infravermelha, que não serve para a fotodissociação, mas apenas para aquecimento parcial da estratosfera durante o inverno antártico. Assim, sem a radiação UV C, não há uma renovação do ozônio, portanto durante o inverno polar a concentração deste gás deverá cair abruptamente. Aliadas a isto, as correntes de jato ao redor de toda a Antártida isolam a base da estratosfera polar da estratosfera das latitudes médias, dificultando a troca do ar rarefeito superior, onde em baixa latitude há uma maior concentração de ozônio, oposto à alta latitude, deficiente deste gás no período invernal. Contudo, ao chegar a primavera, a situação se estabiliza e as concentrações aumentam até o verão austral (Fig.4.2.3A a D). Não é à toa que os alardes sobre tal anomalia acontecem em setembro, quando a diferença da parte polar para a parte das latitudes médias se evidencia muito. Em anos de mínimo solar, as concentrações são baixas sobre a Antártida, mas não devem ser consideradas como alarmantes, mas sim pertencentes ao 


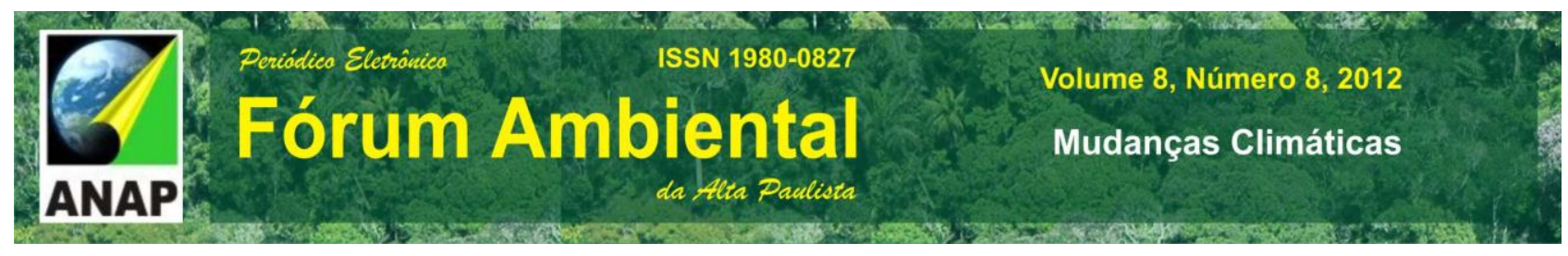

seu ciclo natural, ou seja, são anomalias da suposta normalidade. Esta diferença marcante de ampla anomalia invernal difere da verificada no hemisfério Norte.

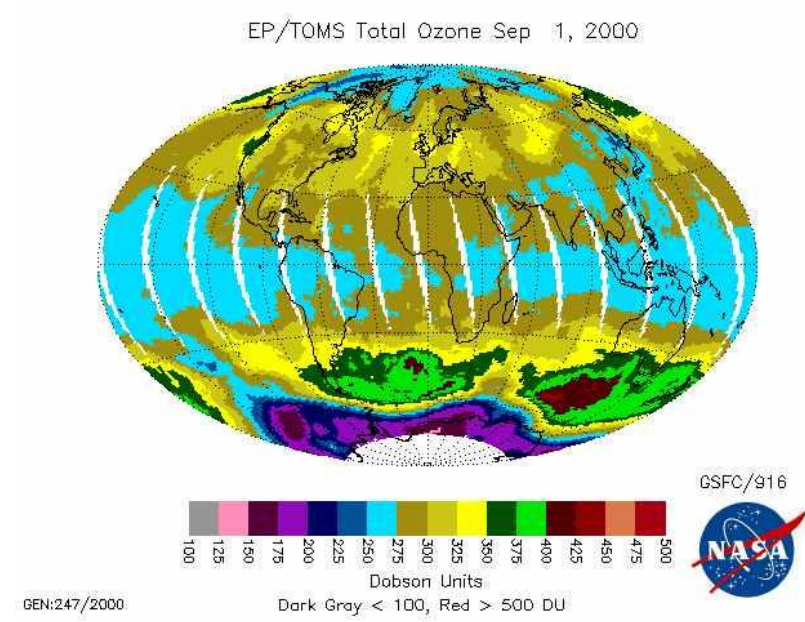

A

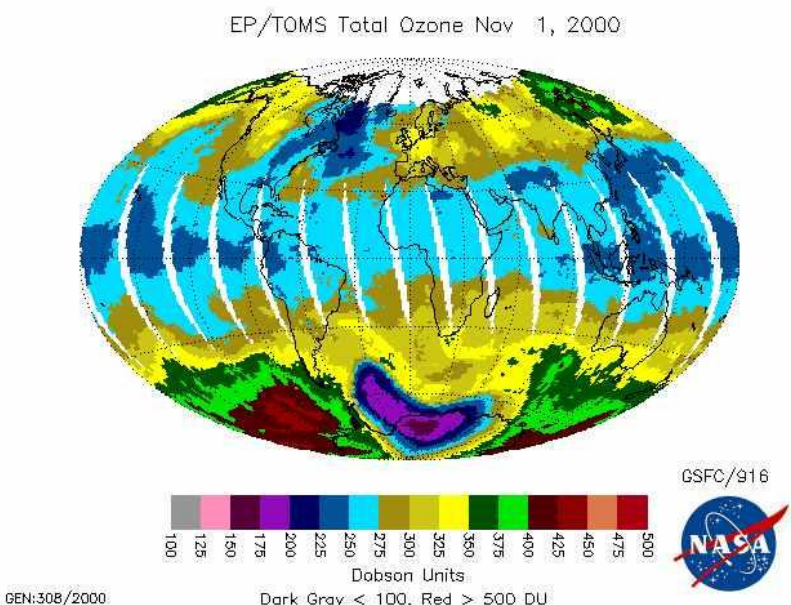

C

Fig.4.2.3A a D: Exemplos de planisférios criados com dados médios de ozônio, obtidos por sensoriamento remoto através do Total Ozone Mapping Spectrometer - TOMS, no ano de 2000. Notar que conforme se passam os meses da primavera para o verão ( $A$ a D), há um significativo aumento do ozônio médio sobre a Antártida e, em geral, no hemisfério Sul. Curiosamente, as informações do hemisfério Norte foram omitidas quando em dezembro, este passa pelo seu período invernal, onde anomalias negativas também apareceriam no cômputo do ozônio (Fonte: NASA, 2000).

\subsection{Criando-se Uma Hipótese Fraudulenta}

Ficou claro que as anomalias do ozônio sempre foram conhecidas e que estas são naturais. Ficou claro também que as anomalias são diferenciadas entre o Ártico e a Antártida e estudos foram realizados para entender e descrever tais fenômenos, incluindo 


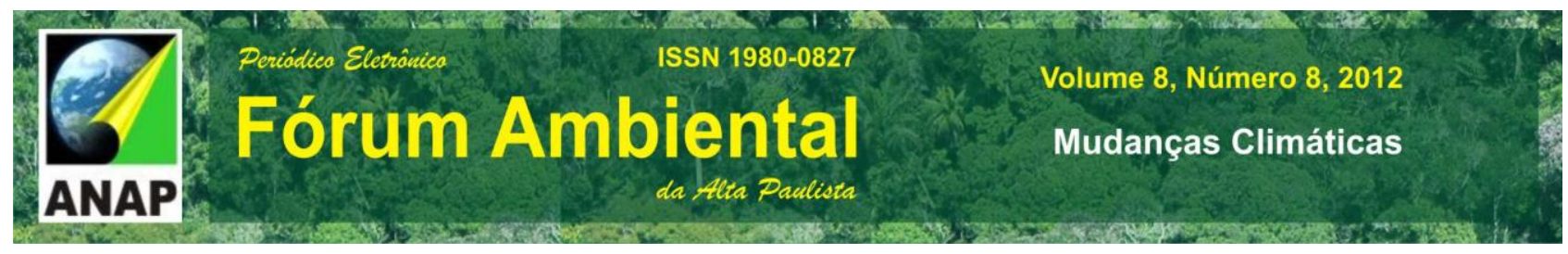

sua geometria. Desta forma, com o advento da era dos satélites, diversos experimentos de medição, teorias e procedimentos foram criados para se poder detectar remotamente do espaço uma gama imensa de fenômenos, muitos deles, é claro, com fins militares. Entre estes, a medição passiva do ozônio, utilizando o Total Ozone Mapping Spectrometer - TOMS, ou Espectrômetro de Mapeamento de Ozônio Total. Tal empreitada foi realizada pelo satélite Nimbus 7, cujo lançamento ocorreu em 1978, dois anos após a morte de Dobson. O Nimbus 7 era um satélite de órbita polar que esquadrinhava passivamente a atmosfera da Terra com o seu TOMS embarcado, utilizando um intrincado processo teórico em que se usam dois radiômetros para realizar um saldo, que no final, gerava uma média. Estas médias dissimulam ou amenizam as informações de máximos e mínimos, tão importantes no cômputo do ozônio e para seu entendimento.

O que se sucedeu a seguir foi um alarmismo global completo, onde a expressão "buracos na camada de ozônio", cunhada anteriormente por R. Penndorf, em 1950, mas então com sentido figurado, impreciso e de ocasião, ficou famosa depois que J. B. Farman, do British Antarctic Survey - BAS, ou Serviço Antártico Britânico, publicou um trabalho na revista Nature, em 1985, utilizando as informações do Nimbus 7 que vinha realizando a montagem de uma série de dados desde 1979, só a encerrando em 1992. Farman utilizou os dados mensais de 1980 a 1984, obtidos do espectrômetro TOMS para tirar a sua conclusão. Ele constatou baixas concentrações de ozônio. Até aqui, nenhuma novidade após verificarmos os trabalhos pretéritos. Notemos então que ele já sabia muito bem o que iria encontrar, uma significativa anomalia do ozônio entre setembro a outubro. $\underline{\text { Além disso, ele também sabia que com o passar dos anos, a anomalia teria boas chances }}$ de ser mais negativa, ou seja, apresentar uma menor concentração de ozônio sobre a Antártida.

Há informações pretéritas que permitem reconstituir estas afirmações. A primeira de que, em 1974, Molina e Rowland começaram a evocar um problema referente ao ozônio, devido particularmente a uma família de substâncias que possuem cloro na sua composição. Passados apenas três anos, em 1977, apenas um ano após a morte de Dobson, os EUA proibiram o uso dos clorofluorcarbonos (CFCs) em aerossóis que não fossem essenciais e outros países como Canadá, Noruega e a Suécia foram diminuindo a 


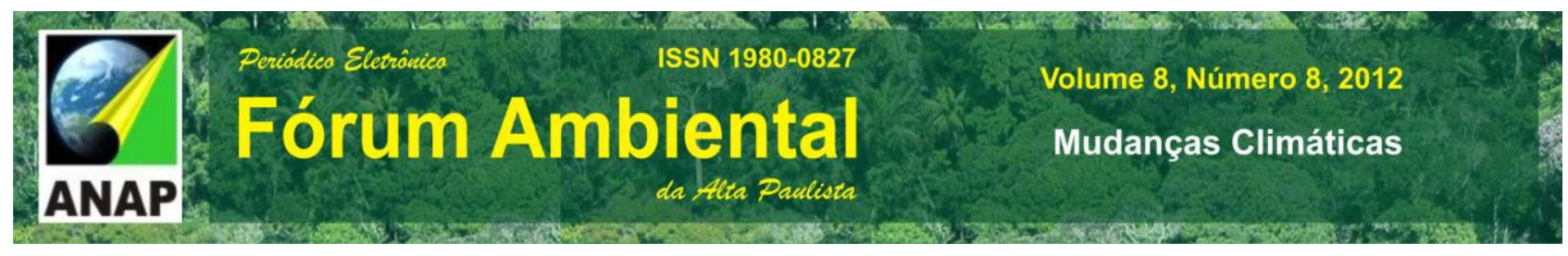

sua produção e uso. No mesmo ano, algumas comissões começaram a se formar. Em março de 1985, em particular, após o "alerta" dado por Farman, a Convenção de Viena estabelecia o Protocolo de Montreal, que correu o mundo atrás de signatários. Em 1987, a NASA responsabiliza-se pela montagem do primeiro painel "científico" mundial para a resolução de um "problema": o Ozone Trends Panel - OTP, ou Painel da Tendência do Ozônio, o qual foi criado para dar o suporte (leia-se legitimação) científico para as decisões políticas que eram tomadas. Este mesmo painel publicou, em 1988, que a "camada de ozônio" sobre os EUA e a Europa havia diminuído em cerca de $3 \%$ entre 1969 a 1986. Tais estudos se mantiveram rigorosamente em segredo e não foram publicados senão dois anos mais tarde (FERREYRA, 2006). Curiosamente, começaram um ano exatamente após o encerramento das pesquisas de Dobson, que trabalhou com a medição do ozônio de 1928 a 1968 ininterruptamente (DOBSON, 1968a; 1968b).

$\mathrm{Na}$ realidade, a informação científica disponível e publicada na revista Science, em 12 de fevereiro de 1988, por J. Scotto, do Biostatic Branch do National Cancer Institute, ou Instituto Nacional do Câncer dos EUA, apresentou sólidas evidências científicas comprovando que a quantidade de radiação UV B que chegava a superfície nos EUA, não

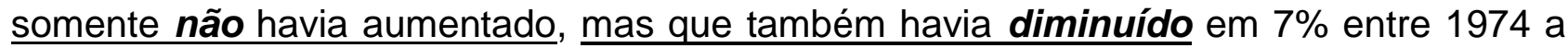
1985. Estes estudos, que foram completamente ignorados pela mídia internacional, estavam baseados em uma rede de monitoramento em superfície que permaneceram registrando diariamente a radiação ultravioleta desde 1974 por medidores RobertsonBerger. Segundo o próprio Scotto:

\begin{abstract}
"Os registros anuais médios de UV B obtidos durante períodos consecutivos cada um com seis anos (1974 a 1979 e 1980 a 1985) mostram uma mudança negativa em cada estação, com diminuições que variam de 2 a $7 \%$ (...) mostram que não existe uma tendência positiva nas leituras de UV B anuais para 1974 a 1985 (...) A mudança da média anual estimada variou de $-1,1 \%$ em Minneápolis, Minnesota; até $-4,0 \%$ em Filadélfia, Pensilvânia. Para todas as estações, as leituras UV B diminuíram em 0,7\% por ano desde 1974." (Fonte: SCOTTO et al., 1988, p.762).
\end{abstract}

Além de Scotto, diversos outros cientistas da época estavam registrando uma diminuição da incidência de radiação ultravioleta que chegava a superfície da Terra. Ele ainda rechaçou, em outro artigo da Science, a possibilidade de a contaminação urbana do ar pudesse dispersar a radiação UV B, causando a diminuição efetiva da radiação UV B 
que chegaria à superfície. Ele ainda recordou a informação da estação de medição na ilha vulcânica de Mauna Loa, no Havaí, a mesma que mede o dióxido de carbono, "teoricamente" livre de contaminação do ar onde as análises preliminares que ele realizou não mostraram nenhum aumento da incidência de radiação UV B entre 1974 e 1985 (FERREYRA, 2006). Levando em conta o que foi explanado anteriormente, se uma quantidade menor de radiação UV B chegava à superfície, significaria então que havia um balanço positivo na produção de ozônio estratosférico nos períodos citados (Fig.4.3.1).

Após este fato de "rebeldia" científica, notemos o que o Establishment científico mundial preparou para a voz dissidente. Scotto não pôde continuar com as suas pesquisas depois de 1985 porque os fundos para o financiamento da maioria das estações de monitoramento da radiação UV B foram cancelados e as estações, que ainda eram resquício do AGI, foram encerradas. O próprio Scotto, um especialista em câncer de renome mundial, não recebeu mais subsídios para viajar para congressos internacionais a fim de apresentar seus descobrimentos sobre a diminuição da incidência de radiação UV $\mathrm{B}$, entrando no chamado "cone de sombra" projetado pelo poderoso lobby político da Ecologia Internacional, coisa muito comum entre os cientistas climáticos atuais que não se calam perante a pseudociência dominante do "aquecimento global antrópico" e das "mudanças climáticas". As vozes dos cientistas que trabalhavam com medição direta de ozônio foram sendo categoricamente silenciadas (FERREYRA, 2006). As estações foram encerradas justamente porque as informações coletadas indicavam uma situação que não corroborava com aquilo que se necessitava, política e economicamente, alardear naquele momento: a noção alarmista de que o ozônio estaria rareando. 


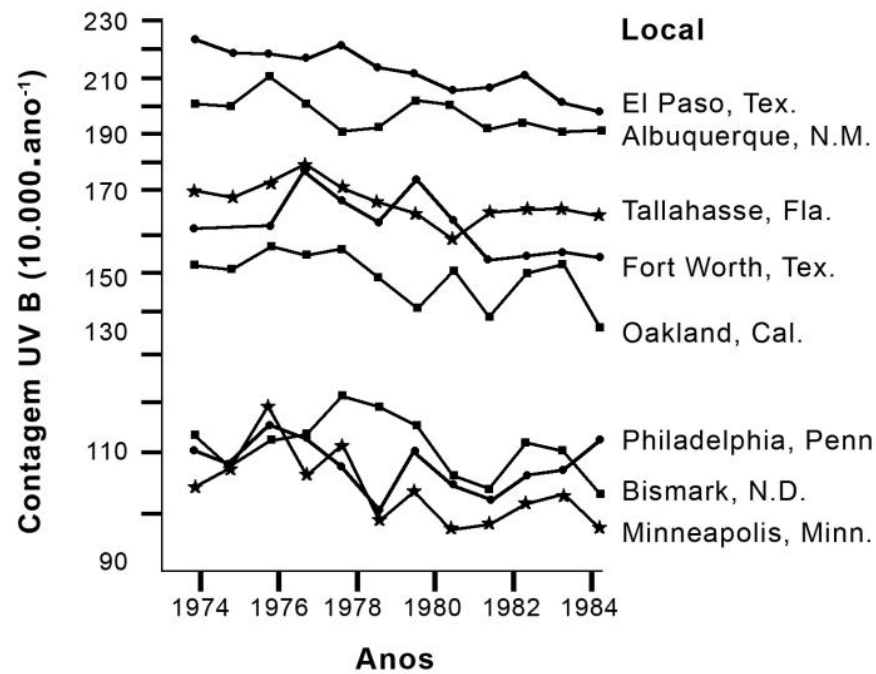

Fig.4.3.1: Séries de dados de diversas estações localizadas nos Estados Unidos da América, de 1974 a 1985. A contagem total de radiação ultravioleta $B$ mostrava redução com o passar dos anos, indicando claramente que aumentava a produção de ozônio, e não ao contrário, como anunciava a mídia da época e outros engajados na causa (Fonte: SCOTTO et al., 1988).

Com o campo aberto e livre de obstáculos, Molina e Rowland levantaram a problemática, justamente quando a produção dos gases CFCs chegaram à cifra de um milhão de toneladas por ano, principalmente para atender aos países em desenvolvimento. Como ambos não entendiam de atmosfera, como era de se esperar, com seus passados de trabalho para a "era nuclear", consultaram alguns especialistas em dinâmica atmosférica e eles acabaram concluindo que os CFCs liberados na Terra, igualmente a qualquer outro gás mais leve que $\mathrm{o}$ ar, tendem a ser dispersos pelos ventos por toda a atmosfera, independentemente do lugar de que tenham sido emitidos (grifos de FERREYRA). Contudo, basta realizar uma pequena operação de cálculo para ver que os gases CFCs, como o Freon-11®, com peso molecular de 137,51 e o Freon-12®, com 121,01, são 4,66 e 4,10 vezes mais pesados que o ar e que os mesmos gases são, 2,46 e 2,16 vezes mais pesados do que o ferro. Desta forma, nunca se explicou como estes gases, normalmente descartados em ambientes controlados, mais pesados que $\mathrm{o}$ ar, poderiam passear pela atmosfera em quantidades excepcionais. Eles tendem a descer aos níveis inferiores da troposfera e podem até circular por ela, dentro dos fenômenos por um período, mas acabariam, em determinado tempo, por se depositar, principalmente sobre os oceanos. Assim, por serem demasiadamente pesados, os CFCs de origem antrópica não subiriam até a estratosfera. Nota-se a diferença entre este 
processo de liberação humana, que ocorre na superfície, e a dos vulcões, que lançam os gases altamente energizados e aquecidos para a estratosfera. Assim, Molina e Rowland lançam a primeira hipótese antrópica para o surgimento de cloro na estratosfera, como o grande vilão do suposto "buraco na camada de ozônio". Os gases CFCs humanos, mesmo altamente estáveis e não reativos, na presença da radiação UV C, que ocorre na parte mais central e alta da estratosfera, seriam rompidos, causando o que eles classificaram como o "ciclo catalítico do cloro":

$$
\begin{aligned}
& \mathrm{Cl}_{3} \mathrm{CF}+\mathrm{hv}(\lambda<230 \mathrm{~nm}) \rightarrow \mathrm{Cl}_{2} \mathrm{CF}+\mathrm{Cl}^{\prime} \\
& \mathrm{Cl}^{\prime}+\mathrm{O}_{3} \rightarrow \mathrm{ClO}+\mathrm{O}_{2} \\
& \mathrm{ClO}+\mathrm{O}^{\prime} \rightarrow \mathrm{O}_{2}+\mathrm{Cl}^{\prime} \\
& \mathrm{NO}_{2}+\mathrm{ClO} \rightarrow \mathrm{ClNO}_{3}
\end{aligned}
$$

Nota-se que no passo os átomos de cloro que se liberaram são extremamente reativos e devem escolher as moléculas de ozônio para produzir o monóxido de cloro do passo , mesmo que as chances disto acontecer sejam altamente improváveis. Além disto, o monóxido de cloro ainda precisaria encontrar um oxigênio atômico liberado para realizar o passo . Com os passos e adicionados, a reação passou a ser virtualmente impossível. Ainda afirmaram que apenas um átomo livre de cloro seria responsável em destruir 100 (cem) mil moléculas de ozônio. Curiosamente, ainda afirmavam que o dióxido de nitrogênio $\left(\mathrm{NO}_{2}\right)$, por ser um dos tantos gases atmosféricos, poderia "seqüestrar" o cloro descrito no passo , produzindo nitrato de cloro $\left(\mathrm{CINO}_{3}\right)$. Esta reação foi chamada de "reação de interferência". Ainda segue que jamais foram encontradas moléculas de CFCs suficientes nas amostras da estratosfera que pudessem ter alguma importância para as tais reações catalíticas do cloro. O que se comprovou em tais amostras é que existem muitos outros gases, tais como hidrogênio, hélio, metano, monóxido de cloro, dióxido de cloro, todos os óxidos de nitrogênio, bem como diversas famílias de gases com bromo, flúor, iodo, além do dióxido de carbono e todos os nobres. Além disto, a necessidade de radiação UV C elege o CFC como um grande flutuador, o que não é, pois radiações desta banda são verificadas a cerca de $40 \mathrm{~km}$ de altitude, onde o oxigênio e nitrogênio são os eleitos a chegar (MADURO e SCHAUERHAMMER, 1992). De fato, a hipótese química de Molina no meio natural seria impossível de ocorrer, pois a mesma 
necessita de calor para que possa acontecer. Na alta altitude da estratosfera sobre o pólo Sul, as temperaturas chegam a $-82,0^{\circ} \mathrm{C}$ na noite polar. Assim, enquanto as reações químicas mágicas de Molina necessitam de calor, o ozônio, por si só, reage com outra molécula dele mesmo, sem nenhuma necessidade especial. A ausência de ozônio na estratosfera não pode ser associada ao cloro, mas sim à nulidade que as próprias moléculas de ozônio produzem ao se interceptarem, aliada a falta completa de radiação UV C que faria a renovação do ozônio, derivado do oxigênio molecular.

O problema vai mais além. Há o fato de as características extremamente particulares necessárias para a depleção do ozônio só serem possíveis de acontecer sobre o núcleo da Antártida no intervalo de cerca de três a quatro semanas após o meio de setembro. Curiosamente, e nunca divulgado pela mídia internacional, neste mesmo período também se encontram diversas ausências de outros gases na alta estratosfera e que deveriam ser convenientemente também chamados de "buracos". Seriam os casos do "buraco do óxido de nitrogênio", "buraco do vapor d’água", não coincidentemente gases derivados dos majoritários na atmosfera, onde o vapor d'água, como substância variável, consegue entrar na atmosfera até 4\%, superando qualquer outro gás, exceto os dois majoritários, $\mathrm{N}_{2}$ e $\mathrm{O}_{2}$ (FERREYRA, 2006).

Não satisfeito, Molina, sempre sendo o auxiliar de Rowland, ainda insiste em uma incrivelmente complexa hipótese química a qual ele vai denominar de química "heterogênica" ou "dímera" onde as temperaturas necessitariam ser extremamente baixas, aquém de $-78,0^{\circ} \mathrm{C}$. Esta situação, como visto anteriormente, pode ocorrer, numa remota possibilidade, quando o Sol "regressa" para o hemisfério Sul, nas primeiras semanas de setembro; estas então seriam as condições ideais para a depleção do ozônio passando por uma nova e mais intrincada combinação de reações químicas, que só existiriam no mundo da fantasia de Molina. Vejamos o porquê:

$$
\begin{aligned}
& \mathrm{ClONO}_{2}+\mathrm{HCl}+\text { gelo } \rightarrow \mathrm{Cl}_{2}+\mathrm{HNO}_{3} \\
& \mathrm{Cl}_{2}+\mathrm{hv} \rightarrow 2 \mathrm{Cl} \\
& \mathrm{Cl}+\mathrm{O}_{3} \rightarrow \mathrm{ClO}+\mathrm{O}_{2} \\
& \mathrm{ClO}+\mathrm{ClO}+\mathrm{M} \rightarrow \mathrm{Cl}_{2} \mathrm{O}_{2}+\mathrm{M} \\
& \mathrm{Cl}_{2} \mathrm{O}_{2}+\mathrm{hv} \rightarrow \mathrm{Cl}+\mathrm{ClOO} \\
& \mathrm{ClOO}+\mathrm{M} \rightarrow \mathrm{Cl}+\mathrm{O}_{2}+\mathrm{M}
\end{aligned}
$$




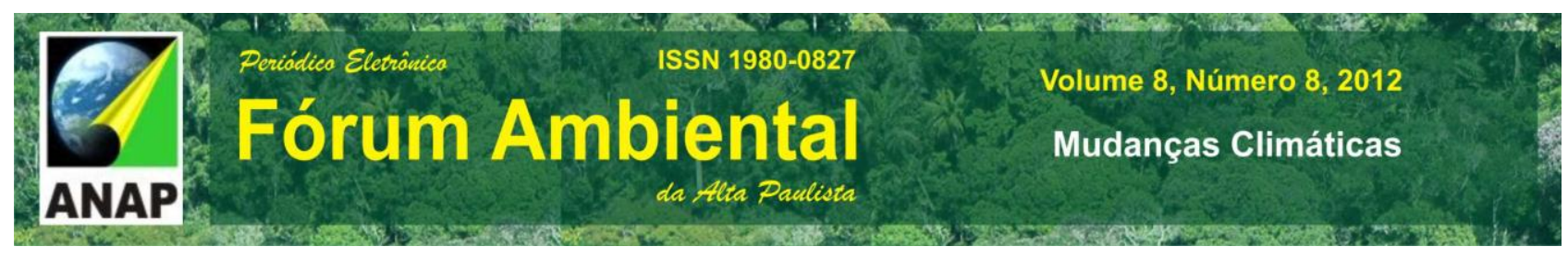

Três pontos tornaram a "nova" hipótese de Molina ainda mais absurda. Primeiro, a existência de um elemento "M", o qual Molina denominou de "acompanhante" para a colisão que deve ser forçada para os dois maiores constituintes atmosféricos em suas formas moleculares, nitrogênio e oxigênio. Usualmente, utiliza-se o símbolo "M" nas reações químicas para um suposto agente que atuaria, de maneira inerte, nas reações, realizando o movimento das mesmas. Neste caso, parece que coube como uma homenagem que Molina quis realizar a si mesmo, pois da alta impossibilidade deste acontecimento, tal ciclo recebeu a alcunha de "ciclo paralítico do cloro" pelos pesquisadores críticos à hipótese (FERREYRA, 2006). Assim, em um balanço líquido, esta complexa série de reações destruiria o ozônio por parte do cloro que apenas supostamente seria provido pelo CFCs. Ferreyra ainda elencou que os CFCs não estão envelopados em nada e o cloro de Molina provém de reservatórios naturais de $\mathrm{ClONO}_{2} \mathrm{e}$ de $\mathrm{HCl}$, como visto na equação . Um segundo absurdo para o processo é que se tornou necessário ter gelo, ou seja, uma superfície sólida para que se possa começar a reação, implicando então na presença de nuvens estratosféricas polares, fenômeno extremamente raro que só apareceria quando houvesse a presença de vapor d'água nestas altitudes, com temperaturas abaixo de $-78,0^{\circ} \mathrm{C}$, na faixa de altitudes de 12 a $20 \mathrm{~km}$, situação claramente difícil de ocorrer pela mesma ausência que exercita o vapor d'água nesta data de inverno. O terceiro, e ainda mais importante absurdo, é que sem a luz solar, ou seja, sem a radiação UV C, estas reações não poderiam ocorrer. Se for observada com cautela apenas a equação, chamada de equação crucial, esta prevê que o peróxido de cloro $\left(\mathrm{Cl}_{2} \mathrm{O}_{2}\right)$ deve receber a radiação UV C para liberar apenas um átomo de cloro instável, o qual deverá buscar o ozônio que porventura encontrar. Deverá também supor que a molécula ClOO colidirá com cristais de gelo para então produzir o oxigênio molecular e finalmente, produzir o cloro atômico.

Desta forma, dado que a teoria jamais tenha sido definitivamente estabelecida em nenhuma prova de laboratório, como aceitar que isto seria o que ocorre na química da estratosfera? Segundo Eberstein, do Goddard Space Flight Center da NASA, ou Centro de Vôo Espacial Goddard, isto não seria possível, pois o caminho mais provável da fotodissociação do peróxido de cloro seria a conversão em dois radicais de monóxido de 
cloro $(\mathrm{ClO})$. Também haveria um caminho secundário de dissociação do gás cloro normal $\left(\mathrm{Cl}_{2}\right)$ e um oxigênio atômico. Estas duas alternativas, completamente naturais, necessitariam de mínima energia para acontecer:

$$
\begin{aligned}
& \mathrm{Cl}_{2} \mathrm{O}_{2}+\text { hv } \rightarrow 2 \mathrm{ClO} \\
& \text { ou } \\
& \mathrm{Cl}_{2} \mathrm{O}_{2}+\text { hv } \rightarrow \mathrm{Cl}_{2} \mathrm{O}+\mathrm{O}^{\prime} \\
& \text { Assim, Eberstein critica com razão: }
\end{aligned}
$$

\begin{abstract}
Não há nenhum mecanismo que dê conta da criação do 'buraco da camada de ozônio'. Esta é uma enorme falha. Se alguém tem uma teoria, deveria esta ser capaz de fornecer um mecanismo definitivo. Caso contrário, é só especulação. Esta questão da diminuição do ozônio da Antártida tem que ser colocada em bases científicas mais sólidas." (Fonte: EBERSTEIN, Geophysical Research Letters, Maio 1990).
\end{abstract}

Ainda houve mais. Após uma série de experimentos de laboratório altamente complexos, Lawrence, Clemitshaw e Apkarian (1990) chegaram a uma conclusão sobre as hipóteses de Molina:

\begin{abstract}
No intervalo espectral que foi recentemente relatado, onde o $\mathrm{ClOO}$ atravessaria por uma dissociação monomolecular para produzir $\mathrm{Cl}+\mathrm{O}_{2}$ (...) temos realizado estudos para estabelecer que, se realmente existe tal canal de fotodissociação, então seu rendimento quântico é menor do que $5 \times 10^{-4}$, um processo com um desempenho quântico tão pequeno seria irrelevante para a fotoquímica do $\mathrm{CIOO}$ na destruição do ozônio estratosférico. (Fonte: LAWRENCE, CLEMITSHAW, APKARIAN, Journal of Geophysical Research, 20/10/1990).
\end{abstract}

Finalmente, a luz solar, que tanto era necessária para a hipótese do "dímero" químico de Molina, como o grande gatilho para o surgimento do "buraco na camada de ozônio" altamente maximizado na entrada da primavera foi novamente derrubado pela Natureza, que insiste em não seguir as regras humanas. Os satélites de órbita polar da National Oceanic and Atmospheric Administration - NOAA, ou Administração Oceânica e atmosférica Nacional, verificaram que o surgimento da anomalia máxima do ozônio ocorria um mês inteiro antes do surgimento do Sol. Assim, as anomalias já estariam muito bem desenvolvidas antes que a luz solar e sua radiação UV C incidissem sobre a estratosfera, sendo então exatamente o contrário do que a hipótese de Molina "previa". Desta forma, se as reações químicas estivessem ocorrendo para criar a anomalia do 
ozônio na estratosfera, estas reações estariam ocorrendo em plena escuridão, o que por si só invalida completamente a hipótese, portanto ela deve ser descartada (FERREYRA, 2006).

Desta forma, se nem mesmo em laboratório foi possível reproduzir a hipótese, como entender que isto seria possível na estratosfera antártica? Ainda avaliando os perfis de temperatura tirados no pólo Sul, pôde-se verificar que a noite polar apresentou temperaturas extremamente baixas, não permitindo haver energia para as reações sugestionadas (Fig.4.3.2). Isto mostrou que se as reações ocorrem para a diminuição do ozônio, elas ocorrem por seus próprios choques. A recuperação da ozonosfera ocorre naturalmente com a chegada da luz solar, renovando a ação rápida de intercâmbio entre oxigênio molecular e o estágio transitório do ozônio. Com a presença do Sol, as temperaturas da estratosfera ficam muito elevadas, dada a incidência permanente de radiação. Desta forma, mais uma vez, com temperaturas elevadas, a teoria de Molina falhou, pois não existem temperaturas abaixo de $-78,0^{\circ} \mathrm{C}$ por todo o período em que o Sol estiver aparente (Fig.4.3.3). Mais uma vez, a hipótese de que estas condições se estabeleçam na estratosfera antártica partiram para o mundo do surreal (KING e TURNER, 1997).

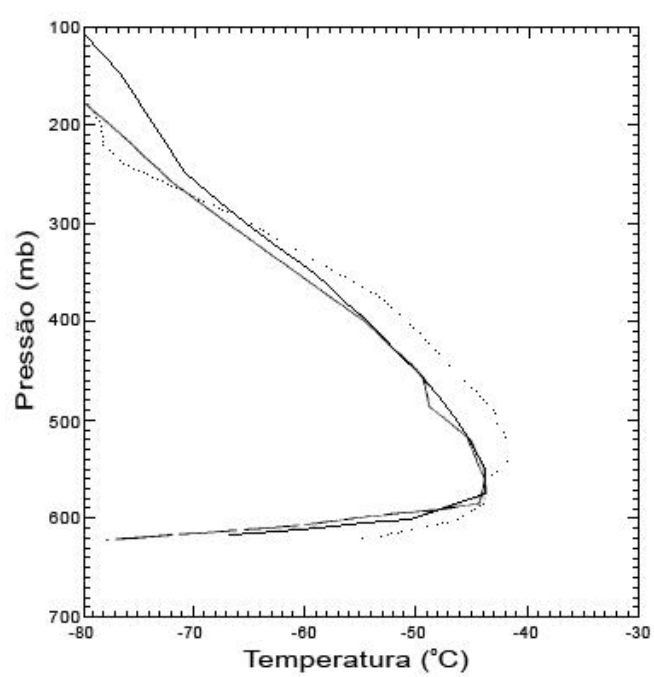

Fig.4.3.2: Perfil de temperatura sobre a estação russa de Vostok (78²7'S 10650'E) em julho de 1989 , plena noite polar de inverno. Verificou-se uma forte inversão de temperatura mais próxima da superfície. A linha cheia indica o perfil médio de temperatura. Notar as temperaturas muito baixas da estratosfera, onde a pressão é mais baixa que $150 \mathrm{mb}$, impossibilitando ter energia para a hipótese de Molina (Fonte: KING e TURNER, 1997, p. 86). 


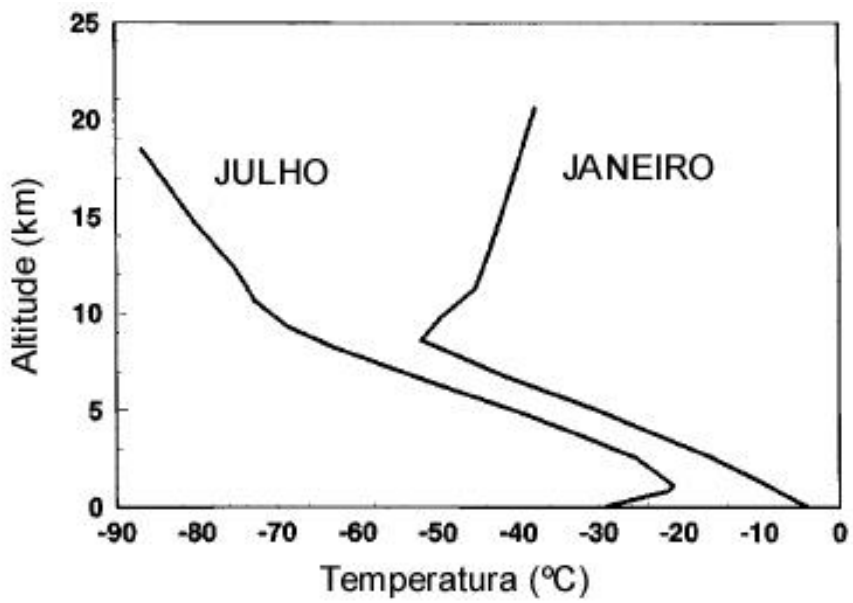

Fig.4.3.3: Perfil médio de temperatura sobre a estação britânica de Halley (75³0'S 026²0'E, em 1996) em julho e janeiro, com dados do período de 1957 a 1993. Notar que em alta altitude, na base da estratosfera, mesmo em uma latitude menor, as temperaturas são muito baixas no inverno, para os meses de julho, mas aumentam significativamente no verão, para os meses de janeiro (Fonte: adaptado por FELICIO de KING e TURNER, 1997, p. 88).

\subsection{Cloro Natural X Antrópico}

E onde entrou o CFC em toda esta história? Como o suposto fornecedor de cloro livre para a estratosfera. A indagação torna-se surpreendente quando se observa quais são as fontes de cloro para a atmosfera e suas escalas. Assim, percebe-se que foi muita pretensão achar que o raro lançamento de um pífio gás para a atmosfera poderia ter, em menos de 50 anos, destruído a tal "camada de ozônio", algo que inclusive não existe. Como, por exemplo, puderam achar que a produção de cloro, supostamente originário dos CFCs, superou a produção dos oceanos e dos vulcões? Observemos as ordens escalares e certos processos. Se os CFCs poderiam produzir no máximo 7.500 (sete mil e quinhentas) toneladas anuais, no seu auge de produção, só a biota oceânica libera 5 (cinco) milhões de toneladas de cloro; os incêndios florestais adicionam, mais 9 (nove) milhões de toneladas; os vulcões do mundo contribuem com 36 (trinta e seis) milhões de toneladas e finalmente, o grande majoritário, os oceanos agregam mais 600 (seiscentos) milhões de toneladas de cloro (Fig.4.4.1). Assim, a quantidade de cloro natural liberado para a atmosfera supera em 80 mil vezes os incriminados CFCs. Não é à toa que não se 
encontram estas moléculas de CFC com facilidade na atmosfera da Terra (MADURO e SCHAUERHAMMER, 1992).

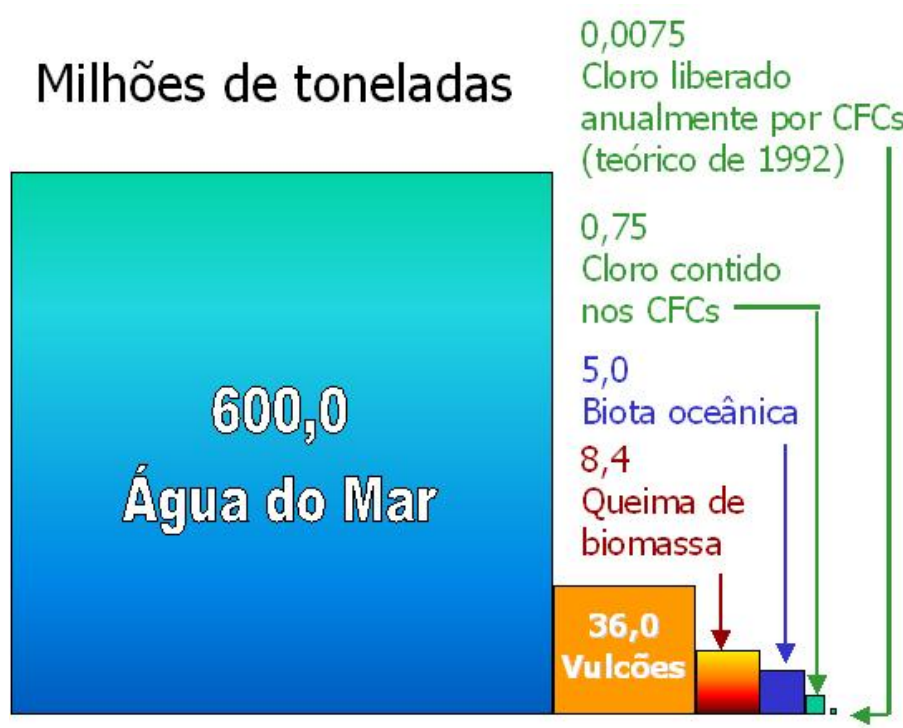

Fig.4.4.1: Esquema pictórico das fontes atmosféricas de cloro, em milhões de toneladas, comparadas em escala com o cloro armazenado nos CFCs e a teórica liberação deste na atmosfera pelos mesmos compostos (Fonte: adaptado por FELICIO de MADURO e SCHAUERHAMMER, 1992).

A maior parte do cloro na atmosfera provém indiscutivelmente dos oceanos, pois durante o processo de evaporação, que é imenso na superfície do mar, as moléculas altamente energizadas acabam carregando sais de cloreto de sódio, um dos principais aerossóis marinhos. $\mathrm{O} \mathrm{NaCl}$ é facilmente carregado pelos processos convectivos por ser leve e participar dos processos de nucleação de gotas, particularmente. Um fato que chamou a atenção foi a notícia que mostrou que telescópios terrestres, de altíssima definição, eram calibrados por feixes pulsadores de LASER, os quais ionizavam átomos livres de sódio $(\mathrm{Na})$ na ionosfera, com o intuito de simular estrelas. A pergunta que deve ser feita é: como o sódio foi parar lá? Se verificarmos que o cloreto de sódio também poderia ser fotodissociado por UV C, teríamos um átomo de sódio livre e, categoricamente, um de cloro livre também.

Além dos oceanos, temos os vulcões. Na Antártida, em particular, o monte Erebus, com 3.794 metros de altitude, situado na ilha de Ross, e ativo desde a data de seu descobrimento em 1841, lança aproximadamente 1.200 toneladas por dia de gás clorídrico $(\mathrm{HCl})$ e 500 toneladas por dia de gás fluorídrico (HF) continuamente, por ser do 


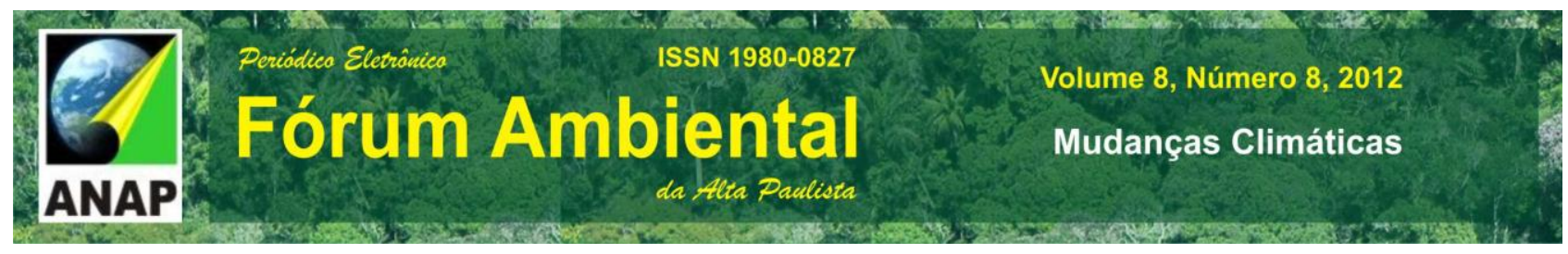

tipo fumegante. Como a troposfera é muito rasa e a estratosfera torna-se muito baixa nesta latitude, principalmente durante o inverno, só o monte Erebus lança 438.000 toneladas de cloro por ano diretamente na faixa onde se formaria o ozônio. Nota-se que além da altíssima quantidade de cloro, ainda temos o lançamento de 182.500 toneladas de flúor, mais ativo ainda que o próprio cloro. Ao se comparar estes valores com 0 lançamento anual da época de 7.500 toneladas por ano de CFCs, verificou-se que só o monte Erebus cobre a "oferta" humana de cloro em cerca de 58,4 vezes, ou seja, em menos de uma semana o vulcão já lançaria toda a produção humana anual dos gases CFCs na atmosfera (MADURO e SCHAUERHAMMER, 1992). Ferreyra ainda lembrou as três campanhas realizadas pelo Dr. Haroun Tazieff ao cume do monte Erebus para estudar os gases lançados, onde comprovou as quantidades especificadas, principalmente devido ao cuidado das circulações de sotavento em sentido a estação estadunidense de McMurdo, que se localiza próxima ao vulcão. Tendo em vista que este fato era conhecido, Susan Solomon, membro do OTP, realizou lançamentos de balões com sensores de cloro nas proximidades da estação de McMurdo Sound, e é claro, "esqueceu" que o monte Erebus fica nas proximidades. Também não mencionou que os balões, assim que lançados no vento "favorável" à barlavento ao monte Erebus, entravam nas plumas de gases lançados pelo vulcão, com as suas centenas de toneladas de $\mathrm{HCl}$ diárias, as quais, em uma troposfera extremamente seca, dada a altitude, têm muitas chances de permanecer por mais tempo que nas regiões tropicais. Convenientemente, também esqueceu que a tropopausa naquelas paragens costuma ocorrer muito mais baixa. Assim, os gases aquecidos rapidamente passariam por esta camada e chegariam à base da estratosfera, que pode estar a cerca de $6 \mathrm{~km}$ de altitude. Quando o Dr. Tazieff chamou a atenção para a contribuição do monte Erebus, simplesmente o ignoraram, pois afinal, como ressaltou Lino, o que um vulcanologista tem a contribuir para uma questão transcendental? (MADURO e SCHAUERHAMMER, 1992).

Desta forma, se há uma suposta presença elevada de cloro na atmosfera da Antártida, ela só poderia ser de origem natural. Jamais deveria ter sido aceita a hipótese de que $90 \%$ dos CFCs que foram liberados no mundo poderiam viajar para a estratosfera antártica e lá serem fotodissociados, principalmente quando a maior parte destes gases era produzida no hemisfério Norte. De fato, desprezou-se propositadamente diversos 
fatores importantes, tais como todo o cloro natural de diversas e imensas fontes, o que inviabilizaria os comentários de um diretor da Du Pont $\AA^{\circledR}$, na época, que afirmava que $95 \%$ do cloro encontrado na Antártida era de origem antrópica (SAGAN, 1998).

Pode-se ir mais além? Sim, quando se estudaram os diversos gases que fazem parte das extensas famílias dos CFCs, os chamados organofluorclorados, ou também os halocarbônicos, verificou-se na literatura que muitos deles fazem parte de ciclos naturais como a "explosão do bromo" $\left(\mathrm{CHBr}_{3}\right)$ cuja origem está ligada às algas. Além deste, às diversas reações que ocorrem na própria neve e gelo quando recém precipitados e pouco maturados na forma de gelo permanente e o recém-descoberto $\mathrm{CH}_{3} \mathrm{Cl}$, cuja fonte seriam as plantas tropicais e material vegetal em decomposição, dos quais ainda nada se conhece (TOMASONI, 2011, apud GEBHARDT, 2008). Notou-se que os halocarbônicos possuem fontes naturais que não podem ser desprezadas, embora possam parecer uma grande surpresa, foram encontrados nas emissões em Vulcano, Itália e medidos diretamente. As concentrações variaram de partes por trilhão - pptv a partes por milhão ppmv. Entre os gases encontrados temos $\mathrm{CH}_{3} \mathrm{Br}_{3}, \mathrm{CH}_{3} \mathrm{Cl}, \mathrm{CH}_{3} l, \mathrm{C}_{2} \mathrm{H} \mathrm{H}_{5} \mathrm{Br}$, além de benzeno-clorados, além do próprio CFC, Freon-11®. (SCHWANDNER et al., 2004). Não obstante, outros pesquisadores como Lutgen, Khalil e Rasmussen demonstraram que a maior parte dos CFCs, por serem gases pesados, como explanado anteriormente, deposita-se no solo e oceanos e serve de alimento para bactérias. No caso dos oceanos, ainda podem ser dissolvidos pela água do mar (LUDGEN, 2006). Também é sabido pela literatura que existem bactérias que vivem em crateras vulcânicas ou nas saídas de vulcões submarinos, consumindo quantidades extremamente altas de enxofre, que seriam consideradas tóxicas para outros seres vivos, bem como as leveduras negras que se alimentam de substâncias extremamente diferentes, como petróleo, benzenos e outros produtos altamente tóxicos. Outros exemplos ainda podem ser elencados, como o microorganismo da espécie Emiliania huxleyi, que vive em altas concentrações de dióxido de carbono, no caso se os oceanos pudessem retê-lo, onde então iriam consumi-lo. Desta forma, estes seres vivos se adaptaram apenas nos últimos 60 anos a aprender a se alimentar de CFCs, em especial o Freon-11®? É claro que não. Tais seres vivos já estão adaptados para isto há milhares de anos, quem sabe até mais, de forma que mais uma vez a Natureza apresentou seus mecanismos para a autorregulação. Assim, 
provavelmente dos estudos dos gases emitidos pelos vulcões, especialistas encontraram aplicações específicas para as características dos materiais halogêneos e os patentearam, não sendo uma descoberta química artificial em particular, mas algo encontrado na própria natureza, ou adaptado desta.

Deve-se relatar ainda que diversos outros gases naturais, que representam uma parcela infinitamente maior dos gases traços, como o $\mathrm{NO}_{2}, \mathrm{CO}_{2}$ e $\mathrm{H}_{2} \mathrm{O}$, este último na sua forma de vapor d'água até $4 \%$, também são fotodissociados quando alcançam a estratosfera, ou às vezes, quando relacionados com as atividades elétricas dos relâmpagos. Sua maior fonte são novamente os oceanos e vulcões, podendo gerar monóxido de nitrogênio (NO), monóxido de carbono (CO), oxigênio atômico (O'), o radical hidroxila $(\mathrm{OH})$ e hidrogênio livre $(\mathrm{H})$.

\section{CONCLUSÃO}

Neste primeiro volume pretendeu-se demonstrar os principais fatos sobre a física e química da formação da altamente variável ozonosfera, as fontes de cloro, a geometria da radiação incidente e os trabalhos de longa data sobre a medição do ozônio e sua variação, altamente conhecida. Também demonstrou-se o quanto a hipótese antrópica, como fonte de cloro é totalmente frágil, principalmente frente às fontes de cloro natural.

No decorrer histórico dos trabalhos, demonstrou-se a mudança de atitude científica frente às questões do ozônio. Ficou nítida a mudança do foco dos trabalhos com dois períodos distintos: desde o início do século XX até a morte de Gordon Dobson e depois na seqüência, o uso do satélite Nimbus 7 aos dias atuais, com o ambientalismo norteando as decisões mundiais.

Ressalta-se mais uma vez que na controvérsia do uso do satélite Nimbus 7, eles sabiam exatamente o que iriam encontrar: uma anomalia de ozônio sobre a Antártida. No caso da estratosfera, a mesma coisa, ou seja, a presença de cloro, mas de fato, se este era originado dos CFCs, nunca foi provado. Foi necessária uma hipótese físico-química absurda, dificilmente realizável em experiência de laboratório, adicionada da presença de cloro na atmosfera, só medido na Antártida, para se corroborar a transformação da 
hipótese fraudulenta em uma teoria. Isto foi um exemplo da distorção completa do método científico consagrado.

\section{HOMENAGEM}

O primeiro volume do artigo é dedicado à memória de Gordon Miller Bourne Dobson (1889-1976), físico e meteorologista britânico, que se tornou a referência mundial sobre o assunto e que realizou medições e estudos por mais de 40 anos, incluindo as observações no continente antártico, métodos de observação noturna, usando as fases da Lua Cheia e muitos outros feitos, dignos dos cientistas pioneiros. Categoricamente, se estivesse vivo, seria um crítico ao que foi postulado logo após a sua morte.

\section{REFERÊNCIAS}

DOBSON, G.M.B. (a) Forty years' research on atmospheric ozone at oxford: a history. In: Applied Optics, Vol. 7, no 3, março p.387-405, 1968.

(b) Exploring the atmosphere. Oxford University Press, Londres, Inglaterra, 1968.

EBERSTEIN, I. J. Photodissociation of $\mathrm{Cl}_{2} \mathrm{O}_{2}$ in the spring Antarctic lower stratosphere. In: Geophysical Research Letters, Vol. 17, (6) maio, p.721-724, 1990.

FERREYRA, E. El fraude del ozonio. In: Ecologia: mitos y fraudes, FAEC, México, Cap. 2, 2006.

KING, J. C. e TURNER, J. Antarctic meteorology and climatology, Cambridge Atmospheric and Space Science Series, Cambridge, Inglaterra, Cap. 1 e 2, 1997.

LAWRENCE, W. G., CLEMITSHAW, K. C. e APKARIAN, V. A. On the relevance of OCIO photodissociation to the destruction of stratospheric ozone. In: Journal of Geophysical Research, Vol. 95 (D11):18, 20/outubro, p.591-595, 1990.

LUTGEN, P. El Agujero de Ozono se Cierra. 2006.

Disponível em <http://www.mitosyfraudes.org/Ozo/OzonoLutgen.html> Acesso em 30 de julho de 2012. 
MADURO, R. A. e SCHAUERHAMMER, R. The holes in the ozone scare: the cientific evidence that the sky isn't falling. $21^{\text {st }}$ Century Science Associates, Washington, D.C. EUA, 1992.

TOMASONI, M. A. Mudanças globais: a problemática do ozônio e algumas de suas implicações. In: GeoTextos, Vol. 7, nº 2, dezembro, p.141-178, 2011.

SAGAN, C. Bilhões e bilhões: reflexões sobre vida e morte na virada do milênio. Ballantine Books, Nova York, EUA, 1998.

SCHWANDNER, F. M., SEWARD, T. M., GIZE, P. A., HALL, P. A., DIETRICH, V. J. Diffuse emission of organic trace gases from the flank and crater of a quiescent active volcano (Vulcano, Aeolian Islands, Italy). In: Journal of Geophysical Research, Vol. 109 (D04301), 18/fevereiro, 20p, 2004.

SCOTTO, J., COTTON, G., URBACK, F. Biologically effective ultraviolet radiation: surface measurements in the United States, 1974-1985. Science Vol. 239, 12/fevereiro, p.762-764, 1988.

Dados de ozônio:

http://ozonewatch.gsfc.nasa.gov/

http://www.cpc.ncep.noaa.gov/products/stratosphere/sbuv2to/archive/latlon/

Agradecimento: Luciana Gerez Campos que realizou um trabalho de recuperação na nitidez das figuras antigas. 